УДК 140.8+37.031

Д-р техн. наук П.І. Мельник (Університет

права імені короля Данила Галицького),

канд. техн. наук В.А. Борщов (УкрДАЗТ),

д-р фіз.-мат. наук А.М. Ніколенко (УкрДАЗТ),

викладачі Т.С. Богданова (Чугуївський

професійний аграрний ліцей),

І.М. Гришина (Харківський коледжс

транспортних технологій)

\title{
ПРОБЛЕМИ ФОРМУВАННЯ СУЧАСНОГО СВІТОГЛЯДУ: КРОНА ТА КОРЕНI
}

\begin{abstract}
Вступ. По суті світогляд людини визначає спосіб духовно-практичного освоєння нею навколишнього світу. Характерна особливість сучасного світогляду полягає в тім, що він $\epsilon$ стохастичним за своїм внутрішнім змістом незалежно від того, стосується це його буденного, релігійного чи філософського аспектів. Трансформація змісту світогляду від механістичного до стохастичного, що відбулася в суспільстві протягом останнього століття, $є$ наслідком застосування імовірнісних концепцій у різних наукових сферах. Розглянемо головні напрями цього процесу більш детально.
\end{abstract}

По-перше, проникнення теоретикоімовірнісних методів у прикладні та фундаментальні науки сприяло зародженню та розвитку спектра якісно нових дисциплін (теорія надійності, статистична механіка, теорія масового обслуговування та ін.). Загальне надбання людства в цьому напрямі полягає в усвідомленні такого факту: звичні нам детерміністичні закони, що в багатьох випадках задовільно описують реальність, насправді репрезентують собою усереднений опис; у переважній же більшості випадків для опису слід застосовувати підхід, основу якого складають імовірнісні концепції. Імовірнісний підхід дозволяє більш адекватно відображати реальність i, що головне, призводить до результатів, які містять у собі результат детерміністичного підходу як окремий випадок.

По-друге, зародження та становлення квантової механіки призвело до розуміння того, що причинність фізичних законів мікросвіту полягає в причинному зв'язку не окремих подій, а потенційних можливостей ix спостереження (тобто імовірностей реалізації цих подій). Надбання людства в цьому напрямі стосується розуміння глибинної суті випадковості та проникнення в діалектику змісту співвідношень між необхідним і випадковим.

По-трете, 3 другої половини $\mathrm{XX}$ століття зусилля вчених були спрямовані на вивчення явищ самоорганізації в природі та суспільстві, результатом чого стало усвідомлення конструктивної ролі флуктуацій у синергічній поведінці складових ієрархічних систем. Загальне надбання людства в цьому напрямі полягає в проникненні в діалектику змісту контроверзи "симетрія-асиметрія" та усвідомленні діалектичної єдності між симетричним і асиметричним, необхідним i випадковим. Саме в цьому напрямі й відбувся якісний стрибок у трансформації світогляду. Достатньо зазначити, що такі загальновживані поняття, як "економічна криза", "технологічний зсув", "революція", "фазове перетворення" та ін., набули в 
результаті принципово нових смислових відтінків, оскільки природа відповідних явищ аналізується тепер у термінах флуктуацій, конфігураційних траєкторій, дисипативних структур, виробництва ентропії, біфуркацій тощо.

Безумовно, всі зазначені результати так чи інакше були втілені в навчальному процесі. Проте 3 недостатнім проникненням у глибинний зміст відповідних навчальних дисциплін. Про це свідчать такі факти. У результаті вивчення елементів теорії надійності чи статистичної механіки студент більш-менш вільно оперує відповідними розрахунковими методами, проте виявляється неспроможним проаналізувати природу випадковості в тих чи інших випадках. Далі, для пересічного студента чи навіть фахівця-інженера (ми не говоримо вже про економістів) $є$ проблематичним пояснити інтуїтивний зміст імовірності, не говорячи вже про здійснення порівняльного аналізу різних інтерпретацій ії. Що ж стосується пояснення фізичного змісту та природи кооперативних явищ, то в цьому випадку можна почути, як правило, лише міркування загального характеру. Більш того, останнім часом спостерігається надто широке, проте необгрунтоване, використання в лексиконі інженерів, педагогів, біологів, економістів, соціологів (не говоримо вже про політиків або діячів літератури та мистецтва) таких фундаментальних наукових понять як "ентропія", "синергізм", "складність", "безлад", що призводить до деформації їх змісту в суспільній свідомості i, як наслідок, окреслює шляхи до помилкових висновків і хибних теорій. Зазначені та подібні їм факти свідчать про наявність у системі освіти проблеми формування сучасного світогляду, зволікання 3 вирішенням якої ставить під загрозу сам процес виховання творчої еліти Держави, що майже не усвідомлюється в суспільстві.

Постановка задачі. Як це не парадоксально звучить, але є всі підстави стверджувати, що саме в період зазначеної вище трансформації світогляду процес викладання дисциплін, відповідальних у системі освіти за його формування, зазнавав занепаду. 3 одного боку, це пов'язано 3 пресингом так званої "марксистсько-ленінської філософії" в системі освіти, 3 іншого боку, причиною тому було невпинне скорочення навчального часу на викладання загальноосвітніх дисциплін, насамперед це стосується загальної фізики та теорії імовірностей. Теоретико-імовірнісні концепції складають підгрунтя сучасних знань 3 природничих i прикладних дисциплін, а також все далі проникають в галузь гуманітарних наук. При цьому в системі вищої освіти теорія імовірностей відіграє подвійну роль: з одного боку, вона забезпечує вивчення професійноорієнтованих дисциплін і в цьому плані традиційно виступає як загальноосвітня дисципліна; з іншого боку, вона забезпечує якісний стрибок у пізнавальній діяльності людини, який полягає в переході від індивідуального до стохастичного опису явищ навколишнього світу в процесі їх пізнання, і в цьому плані відіграє провідну роль у формуванні сучасного світогляду. Отже, роль теорії імовірностей у вихованні сучасного фахівця $є$ справді унікальною, проте статус іiі в системі вищої освіти не відповідає статусу провідної загальноосвітньої дисципліни. Останнє означає, що основу проблеми виховання стохастичного світогляду складає інша проблема, пов'язана 3 викладанням теорії імовірностей, що лишається майже непомітною, бо існує по суті в завуальованому вигляді.

Існує добре опрацьований своєрідний міжнародний стандарт, що визначає ядро змісту навчальних програм 3 теорії імовірностей у вищій школі. Програми ці, як правило, включають навчальні модулі, що стосуються основних понять дисципліни; класичної та статистичної інтерпретацій імовірності; комбінаторики 
та опису випадкових подій; опису випадкових величин і систем випадкових величин; опису функцій випадкових величин; елементів теорії випадкових процесів; граничних теорем; практичних застосувань теорії. Зазначений спектр навчальних модулів цілком відповідає сучасним вимогам що вищої освіти, але ж і зазначена проблема $\epsilon$ цілком реальною. Отже, першопричину проблеми слід шукати не в змісті навчальних програм, а в технології втілення їх у навчальному процесі.

Аналіз публікацій i результати досліджень. Зауважимо перш за все, що теорія імовірностей у вищому навчальному закладі (ВН3) інженерно-технічного та педагогічного профілю входить, як правило, до складу курсу вищої математики як окремий розділ, на вивчення якого планується явно недостатньо часу, що може бути скороченим на користь інших розділів курсу. Здавалося б, напрошується очевидний висновок: теорію імовірностей у ВН3 зазначеного спрямування слід викладати як окрему дисципліну, достатньо забезпечивши цей процес 3 бюджету навчального часу. Проте у ВН3 економічного спрямування теорія імовірностей викладається як окрема дисципліна, на опанування якої виділяється достатньо часу, але й там викладачі таких дисциплін, як "Економетрія" або "Економічний ризик та основи його вимірювання", стикаються 3 тими самими невідповідностями. Це свідчить не стільки про наявність проблеми 3 викладанням теорії імовірностей (бо актуальність іiі слід було б сприймати як аксіому), скільки про явне недооцінювання значення вирішення ㄲï для систем вищої освіти в цілому. Вирішення цієї проблеми може уможливити лише конструктивна перебудова тих елементів державних стандартів освіти, які стосуються зазначеної дисципліни. Передусім це стосується визначення належного місця теорії імовірностей у системі освіти взагалі та співвідношень іiі 3 іншими загальноосвітніми дисциплінами.

Зустрічається іноді думка, що лише за традицією теорію імовірностей відносять до складу математичних дисциплін. Приміром, деякі фізики розглядають вчення про імовірність як фізичну науку. Думка ця є не новою. У 1900 році на Міжнародному математичному конгресі в Парижі, видатний німецький математик Д. Гілберт анонсував 23 невирішені на той час проблеми (так звані "проблеми Гілберта") [1]. Шоста проблема Гілберта стосувалася також теорії імовірностей: "3 дослідженнями 3 основ геометрії близько пов'язана задача про аксіоматичну побудову за тим же зразком тих фізичних дисциплін, у яких уже тепер математика відіграє головну роль: у першу чергу теорія імовірностей i механіка". Отже, чітко розуміючи актуальність проблеми аксіоматичної побудови теорії імовірностей, Д. Гілберт не вважав іiі при цьому розділом математики.

Аналізуючи причини появи подібних міркувань, видатний український математик, фахівець 3 теорії імовірностей А.В. Скороход звертає увагу на три основні особливості, що споріднюють теорію імовірностей 3 теоретичною фізикою [2]: 1) інтуїтивність термінів i відсутність багатоповерхових абстракцій; 2) складність математичного апарату, який використовується для розв'язання задач з відносно простим формулюванням; 3) існування наближених методів розв'язання цих задач, що уможливлює реалізацію якісного опису ситуації.

Безумовно, зазначені особливості теорії імовірностей орієнтують на висновок про доцільність розглядати ії як самостійну природничу дисципліну, принаймні в рамках вищої школи. Проте не цей висновок $\epsilon$ важливим для нас, а та обставина, що здобутки вітчизняної освіти у викладанні фізики та інших природничих дисциплін можуть скласти основу розробок конструктивної стратегії викладання цієї 
дисципліни у вищій школі в таких напрямках.

По-перше, оволодіння імовірнісними методами в системі вищої освіти вбачається доцільним реалізувати як дворівневе (аналогом тому $є$ послідовне викладання курсів загальної та теоретичної фізики). Очевидно, перший рівень повинен передбачати оволодіння основами дисципліни та загальними методами практичних застосувань іiі (саме на цьому рівні й повинне здійснюватися формування стохастичного світогляду студента). Другий рівень слід розглядати як такий, що відповідає спеціальному курсу теоретичного характеру в системі підготовки магістрів.

По-друге, курс теорії імовірностей першого рівня слід розглядати як обов'язковий у системі підготовки бакалаврів незалежно від майбутньої фахової орієнтації їх. Між іншим, ця думка $\epsilon$ співзвучно міркуванням Ч. Сноу, викладеним ним майже 50 років тому у відомій лекцій "Дві культури" [3], де автор обстоює таку систему освіти, в рамках якої майбутні гуманітарії добре розуміють внутрішній зміст поняття ентропії, а фізики можуть вільно обговорювати глибинну суть взаємостосунків шекспірівських героїв. Проте не це $\epsilon$ основним аргументом на користь необхідності загального виховання стохастичного світогляду, а та обставина, що саме він складає основу розуміння суті суспільних i природних явищ 3 позиції аналізу їх як результатів синергічних процесів у відповідних складних системах.

По-третє, викладання курсу теорії імовірностей першого рівня повинне бути узгодженим з викладанням курсу філософії. Цей напрям перебудови системи вищої освіти стосується насамперед викладачів, що здобули освіту в часи пресингу так званої «марксистсько-ленінської філософії». Стосовно теорії імовірностей це проявляється в неповноті тодішнього сприйняття, а нинішнього викладання саме основних понять дисципліни. Наприклад, статистична (об'єктивістська) інтерпретація імовірності часто розглядається не просто як єдино правильна, а як єдина. А що може при цьому думати студент про імовірність реалізації події, яка відповідає унікальному випадковому явищу (наприклад, про імовірність ясної погоди завтра вранці)? Отже, відповідні навчальні плани повинні передбачати досталь часу на детальне обговорення питань, пов'язаних 3 різними інтерпретаціями (об'єктивістською, імовірності індуктивною та ін.), діалектикою взаємовідношень випадкового та необхідного, визначенням природи випадковості, що проявляється в різних реальних та уявних ситуаціях, гносеологічних аспектах стохастичного відображення реальності.

По-четверте, основу переорієнтації людини в бік стохастичного сприйняття та відображення явищ навколишнього світу можна забезпечити лише попереднім переосмисленням широкого спектра стереотипів, цілеспрямованим, але й поступовим. Саме поступовість цього процесу і $є$ тією відмінною рисою його, яка свідчить $з$ нашого погляду, про принципову неможливість реалізації його лише в рамках вищої школи. Стохастичне світосприйняття слід починати формувати в людини в ранні періоди пізнавальної діяльності ії. Це, у свою чергу, свідчить що користь висновку про те, що корені проблеми виховання стохастичного світогляду містяться в системі загальної освіти.

Нам вбачається доцільним запровадження вивчення основних понять вчення про імовірність у школі II та III ступенів: а) у школі II ступеня елементи стохастичного опису явищ навколишнього світу можуть складати окремий розділ такої дисципліни, як "Природознавство"; б) у школі III ступеня до навчальних програм доцільним було ввести окрему дисципліну "Основи теорії імовірностей", обмежившись у ній детальним 
обговоренням основних понять, елементами комбінаторики та основами аналізу випадкових подій, основами аналізу випадкових величин, загальними уявленнями про граничні закони та елементарними застосуваннями результатів у теорії аналізу похибок вимірювань. При цьому слід дотримуватися таких вимог: 1) зазначені елементи вчення про імовірність повинні входити до комплексу основних, а не варіативних програм; 2) вчення про імовірність у загальноосвітній школі повинне мати статус окремої навчальної дисципліни, а не входити окремим розділом до курсу математики, оскільки метою його вивчення $\epsilon$ розвиток "імовірнісної" інтуїції, що суттєво відрізняється від інтуїції математичної; 3) навчальні програми повинні передбачати зв'язок вчення про імовірність 3 іншими дисциплінами: фізикою (наприклад, при вивченні молекулярно-кінетичної теорії чи елементів квантової фізики); біологією (наприклад, при вивченні основ еволюційної теорії чи закономірностей спадковості); хімією (наприклад, при вивченні елементів хімічної кінетики); історією (наприклад, у рамках аналізу рушійних сил історії) та ін.

Звернемося тепер до стану викладення загальної фізики у вищій школі. Ця дисципліна традиційно вивчалася на молодших курсах ВНЗ і природно увійшла свого часу до складу загальноосвітніх дисциплін, що забезпечують підготовку бакалаврів. Проте за останні десятиліття відбулося суттєве скорочення навчального часу на вивчення загальної фізики в системі виховання інженерів і педагогів, програми ж підготовки фахівців гуманітарного профілю взагалі не передбачають вивчення цієї дисципліни. Зауважуючи ту обставину, що загальна фізика $є$ однією 3 провідних дисциплін, які забезпечують формування сучасного світогляду, слід визнати, що стан викладання іii в системі підготовки бакалаврів необхідно переглянути в процесі розроблення нових Державних стандартів освіти.

Доцільним вбачається також розглянути в рамках реформування системи вищої освіти можливість дворівневого викладення курсу загальної фізики аналогічно тому, про що говорилося вище стосовно теорії імовірностей. Мається на увазі запровадження в системі підготовки магістрів курсу загальної фізики підвищеного рівня, орієнтованого на вивчення основ еволюції складних систем. Можливо, що такий курс має складатися 3 двох частин - загальної (яка забезпечувала б основу досліджень явищ самоорганізації) і фахово орієнтованої (яка стосувалася б вивчення явищ, які стосуються майбутнього фаху студента безпосередньо).

Висновки. Зауважимо насамкінець, що дана стаття репрезентує по суті точку зору викладачів на проблему, що обговорюється, i на можливі шляхи піi подолання. Подібна точка зору має певний сенс, оскільки і теорія імовірностей, і фізика уособлюють собою мистецтво вирішення проблем навколишнього світу, тому їх і треба вивчати як мистецтво послідовно та виважено. Безумовно, відповідні методики навчання, відшліфовані в процесі викладання насамперед фізики, не можуть бути перенесені на новий грунт без пересторог i переосмислення, проте вони являють собою надійну основу розроблення стратегії вирішення розглянутої проблеми та шляхів реалізації цієї стратегії.

\section{Список літератури}

1. Проблемы Гильберта [Текст]: сборник / под общ. ред. П.С. Александрова. - М.: Наука, 1969. - 240 с. 
2. Скороход, А.В. Особливий характер теорії ймовірностей в математичних науках [Текст] / А.В. Скороход // У світі математики. - 1997. - Т. 3. - Вип. 2. - С. 2-4.

3. Сноу, Ч.П. Две культуры и научная революция [Текст] / Чарлз Перси Сноу // Сноу Ч.П. Портреты и размышления. - М.: Прогресс, 1985. - С. 195-226.

Ключові слова: світогляд, трансформація змісту світогляду, теоретико-імовірнісні концепції, імовірнісний підхід, стохастичний опис явищ, синергічний процес, формування стохастичного світосприйняття та світогляду.

\section{Анотації}

Розглянуто особливості сучасного світогляду. Проаналізовано причини його деформації та запропоновано основні можливі шляхи подолання проблем формування сучасного світогляду.

Рассмотрены особенности современного мировоззрения. Проанализированы причины его деформации и предложены основные возможные пути преодоления проблем формирования современного мировоззрения.

The particularities of the modern worldview are considered. The reasons of the warp of the worldview analyzed and main possible ways of problems overcoming of the modern worldview formation offered. 